\title{
Physicochemical and pasting properties of starch extracted from four yam varieties
}

\author{
Addy Ransford Nii Amoo*, Wireko-Manu Faustina Dufie, Oduro Ibok
}

Kwame Nkrumah University of Science and Technology, Kumasi, Ghana

Email address:

ransfordaddy@live.com (R. N. A. Addy)

\section{To cite this article:}

Addy Ransford Nii Amoo, Wireko-Manu Faustina Dufie, Oduro Ibok. Physicochemical and Pasting Properties of Starch Extracted from Four Yam Varieties. Journal of Food and Nutrition Sciences. Vol. 2, No. 6, 2014, pp. 262-269. doi: 10.11648/j.jfns.20140206.14

\begin{abstract}
Yams are not among the most common sources of industrial starch, which are mostly imported at a cost. Exploiting alternative sources of starch would lessen the burden of its importation. Starches from four local varieties of Dioscorea rotundata namely Pona, Labreko, Asobayere and Muchumudu were analyzed for their physicochemical and functional properties. Results obtained showed significant differences $(\mathrm{p}<0.05)$ in some physicochemical properties (moisture, ash, starch yield and $\mathrm{pH}$ ). Moisture, ash, starch yield, $\mathrm{pH}$, amylose, amylopectin, swelling power, solubility and water binding capacities ranged from 7.22 to $7.82 \%, 024$ to $0.86 \%, 12.61$ to $20.89 \%, 5.57$ to $6.25,27.48$ to $31.55 \%, 68.45$ to $72.52 \%, 10.57$ to $12.48 \%, 8.52$ to $9.32 \%$ and 175.25 to $182.69 \%$ respectively. Asobayere had the highest starch yield (20.89\%) and may be exploited for starch production. There were significant differences $(\mathrm{p}<0.05)$ in the pasting properties. The pasting temperature ranged from 75.10 (Asobayere) to $77.30^{\circ} \mathrm{C}($ Muchumudu) . Peak temperature ranged from 81.7 (Asobayere) to $94.8^{\circ} \mathrm{C}$ (Muchumudu). Peak viscosity for Asobayere, Pona, Labreko and Muchumudu were 726, 614, 685 and 639 BU respectively. Final viscosity ranged from 385 (Pona) to 817 BU (Muchumudu). Values of 385 (Asobayere), 142 (Labreko), 293 (Pona) and 25 BU (Muchumudu) were observed for breakdown viscosity. Labreko had the highest value of $337 \mathrm{BU}$ and Pona the lowest value of 79 BU for setback viscosity. Muchumudu may be used industrially in products that require high unit yield, low viscosity and paste stability at low temperatures. Asobayere and Labreko may be used for foods that require thick and cohesive paste such as fufu and pounded yam due to its high pasting viscosities. Yam starches can be exploited for diverse uses.
\end{abstract}

Keywords: Physicochemical, Pasting Properties, Starch, Yam

\section{Introduction}

Yams (Dioscorea spp.) are annual or perennial climbing plants with underground tubers that are suitable for eating. Yams are of great economic importance and nourishment to the people of Africa, the Caribbean, Asia and America [1]. There are some 600 species [2] of yam, but only six are mostly grown as staple foods. These are Dioscorea rotundata (white yam), D. alata (water yam), D. cayenensis (yellow yam), $D$. esculenta (Chinese yam), D. bulbifera (aerial yam) and $D$. dumetorum (trifoliate yam) [3]. Out of the six species commonly found in West Africa, D. rotundata is the most widely grown and generally considered to be the best in terms of food quality, thus commanding the highest market value ([4]; [3]).

Starch is the main component of yam and provides large proportion of daily caloric intake. The value of the yam as a basic food has been attributed to the high digestibility of its starch, which is present in the form of small granules [5]. Since yam tubers contain about $70-82 \%$ starch [6], the cooking and processing characteristics of yams, the eating and storage quality of yam-containing products, and perhaps the physiological effectiveness of the bioactive ingredients involved will be greatly dependent on starch properties [7].

Yam ranks second after pineapple in terms of volume and value of non-traditional export crops in Ghana [8]. In 2005, the value of non-traditional exports from Ghana increased by $10.2 \%$ from US\$705.4 million in 2004 to US\$777.6 million [9].

Ghana is the third largest producer of yam in the world [10], however, due to the poor shelf life of the yam tubers, a substantial amount is lost during storage. These post-harvest losses are as a result of weight loss, sprouting, rotting, and insect infestation. There is a need to expand utilization of yam through industrial processing to minimize postharvest losses. Reduction in post-harvest losses of the tuber may lead to 
increased earnings from this crop. The starch content of the tubers presents a prospect for the processing of yams into starches. Currently, yams are not listed among the most common sources of industrial starch which is principally provided by corn, potato, wheat, tapioca and rice ([11]; [12]; [13]).

Starch is an important raw material for a number of industries including textiles, paper, adhesives, pharmaceuticals and food. As a country becomes more industrialized, demand for both native and modified starches increases, but this demand is typically met through imports rather than locally made starch. In 1996, the starch market in Ghana was about 4,200 tonnes, most of this starch was imported and $60 \%$ of the market went to modified starches with high product specifications [14]. Important to these major industrial uses of starch are the amount and quality of starch obtained from the crop.

Lack of adequate information on the physiochemical and pasting properties of the starches is one of the limiting factors for industrial application of non-official starches such as that from yams [15]. The potential of yam to be processed into value-added products would be influenced by their physical and chemical properties such as moisture, ash, amylose and amylopectin contents. The objective of this study was therefore designed to examine the physicochemical and pasting properties of starches isolated from four D. rotundata varieties.

\section{Materials and Methods}

\subsection{Source of Materials}

Four Dioscorea rotundata varieties (Pona, Labreko, Asobayere and Muchumudu) were obtained were obtained from two farmers at a market in Ashanti Mampong 24 hours after harvest.

\subsection{Starch Extraction}

Starch was extracted from freshly harvested yam by the wet extraction method described by Ellis [16]. The yams were first sorted out and then peeled with knife. The peeled yam was washed with tap water to remove all dirt and cut into chunks of about 2-3 grams sizes. One kilogram of the chunks were weighed and ground with $500 \mathrm{ml}$ of distilled water using the Waring Blender (Model 51BL30 (7010), Torrington, Connecticut, USA). The slurry obtained was pressed through clean cheese cloth. The solids retained by the cloth were mixed with $1500 \mathrm{ml}$ of distilled water and the resulting slurry pressed through clean cheese cloth. This process was repeated until there was little or no starch in the residue. Starch in filtrate was allowed to sediment for 3 hours after which the supernatant was decanted and discarded. The starch was re-suspended starch in $500 \mathrm{ml}$ of distilled water and the sedimentation and decanting steps repeated without pressing through cheese cloth. The starch was dried using solar dryers for 48 hours. The dried starch was ground into powder using a Waring Blender (Model 51BL30 (7010),
Torrington, Connecticut, USA) and then stored in low density polyethylene zip-lock bags prior to use.

\subsection{Starch Yield}

Starch yield was determined as the percentage starch recovered after extraction from a weighed kilogram of yam.

\subsection{Determination of Physicochemical Properties}

\subsubsection{Chemical Analysis}

The moisture and ash contents were determined using the Official Methods of Analysis [17]. Five grams of chopped fresh yam tuber was weighed and transferred into a previously dried and weighed glass dishes. The dishes with yam samples were placed in a thermostatically controlled oven and heated at $105^{\circ} \mathrm{C}$ for 5 hours to a constant weight. The dishes were removed and cooled in a desiccator and re-weighed. The dishes were dried again for 30 minutes, cooled down and weighed. The moisture content was then determined by difference and expressed as a percentage. The ash content was determined by weighing $2 \mathrm{~g}$ of starch into a porcelain crucible which had previously been ignited, cooled and weighed. The crucible and its contents were then placed in a muffle furnace preheated to $600^{\circ} \mathrm{C}$ for 2 hours. The crucible was removed and cooled in a desiccator. The crucible and its contents were weighed. The total ash content was calculated and expressed as a percentage.

\subsection{2. $\mathrm{pH}$}

Five grams of yam starch was weighed and mixed with 50 $\mathrm{ml}$ of distilled water to obtain slurry. The $\mathrm{pH}$ was then determined using a Fisher Science Education $\mathrm{pH}$ meter (Model S90526, Singapore) meter by inserting the $\mathrm{pH}$ probe into the slurry.

\subsubsection{Determination of Amylose}

The amylose content of the yam starch was determined based on the iodine colorimetric method of Williams [18] and Juliano [19]. About $0.1 \mathrm{~g}$ of the starch sample was solubilised with $1 \mathrm{ml}$ of $95 \%$ ethanol and $9 \mathrm{ml}$ of $1 \mathrm{~N} \mathrm{NaOH}$, and heated in a boiling water bath for $10 \mathrm{~min} ; 1 \mathrm{ml}$ of the extract was made up to $10 \mathrm{ml}$ with distilled water. To $0.5 \mathrm{ml}$ of the diluted extract was added $0.1 \mathrm{ml} \mathrm{I} \mathrm{N}$ acetic acid and $0.2 \mathrm{ml}$ iodine solution $(0.2 \mathrm{~g} \mathrm{I} 2+2.0 \mathrm{~g} \mathrm{KI}$ in $100 \mathrm{ml}$ of distilled water) to develop a dark blue colour. The coloured solution was made up to $10 \mathrm{ml}$ with distilled water and allowed to stand for $20 \mathrm{~min}$ for complete colour development. The solution was vortexed and its absorbance was read on a spectrophotometer at $620 \mathrm{~nm}$. Absorbance of standard corn amylose with known amylose concentration was used to estimate the amylose content.

\subsubsection{Determination of Water Binding Capacity}

Water binding capacity of yam starch was determined according to the method of Yamazaki [20] as modified by Medcalf and Gilles [21]. An aqueous suspension of yam starch was made by dissolving 2.0 grams (dry weight) of starch in $40 \mathrm{ml}$ of distilled water. The suspension was 
agitated for 1 hour on a Griffin flask shakes and centrifuged at $2200 \mathrm{rpm}$ for 10 minutes. The free water was decanted from the wet starch, drained for 10 minutes and the wet starch was then weighed.

\subsubsection{Solubility and Swelling Power}

This was carried out based on a modification of the method of Leach [22]. One gram of yam starch was dissolved with distilled water to a total volume of $40 \mathrm{ml}$ using a weighed 50 $\mathrm{ml}$ graduated centrifuge tube. The suspension was stirred just sufficiently and uniformly avoiding excessive speed since it might cause fragmentation of the starch granules. The slurry in the tube was heated at $85^{\circ} \mathrm{C}$ in a thermostatically regulated temperature water bath for 30 minutes with constant gentle stirring which might lead to lower value for swelling power [16]. The tube was then removed, wiped dry on the outside and cooled to room temperature. It was then centrifuged at $2200 \mathrm{rpm}$ for 15 minutes. The supernatant was decanted into a pre-weighed moisture can. The solubility was determined by evaporating the supernatant in a thermostatically controlled drying oven at $105^{\circ} \mathrm{C}$ and weighing the residue. The sedimented paste was weighed. The swelling power was calculated as the weight of sedimented paste per gram of starch used, with a correction applied for starch soluble.

\subsection{Determination of Pasting Properties}

A smooth paste was made from the extracted starches $(40 \mathrm{~g})$ in $420 \mathrm{ml}$ distilled water $(8.8 \%$ slurry) for viscoelastic properties using Brabender Viscoamylograph (Viskograph-E, Brabender Instrument Inc. Duisburg, Germany) equipped with a $1000 \mathrm{cmg}$ sensitivity cartridge. The smooth paste was heated at a rate of $1.5^{\circ} \mathrm{C} \min ^{-1}$ to $95^{\circ} \mathrm{C}$ and maintained for $15 \mathrm{~min}$. Viscosity profile indices were recorded for pasting temperature, peak temperature, peak viscosity, viscosity at $95^{\circ} \mathrm{C}$, viscosity after $15 \mathrm{~min}$ hold at $95^{\circ} \mathrm{C}\left(95^{\circ} \mathrm{C}\right.$ Hold or Hot Paste Viscosity), viscosity at $50^{\circ} \mathrm{C}$, viscosity after $15 \mathrm{~min}$ hold at $50^{\circ} \mathrm{C}\left(50^{\circ} \mathrm{C}\right.$ Hold or Cold Paste Viscosity), breakdown and setback as described by Shuey and Tipples [23] and Walker [24].

\subsection{Determination of Starch Granule Size and Shape}

The size and shape of starch granules were obtained from extracted yam starch samples. A small amount of starch powder was scooped with a spatula onto a clean micro-slide (75 x $25 \mathrm{~mm})$. A drop of distilled water was added and distributed thinly on the slide and covered with a slip. Starch granules were observed under a light microscope (LEICA CME, Leica Microsystems) and sizes were determined by measuring the granule diameter with an ocular micrometer fixed to the lens of the microscope. The actual sizes of the granules were calculated by multiplying their mean diameters by a factor of $2.47 \mu \mathrm{m}$ (i. e. the factor for objective magnification that was used) which was calculated earlier using the parallax obtained between a stage micrometer (Graticules Ltd, Tonbridge, England) and the calibrations of the eye piece.. A minimum of 10 granules were selected randomly and measured for each variety. Observation was done under x 400 magnification.

\subsection{Statistical Analysis}

Data obtained was subjected to one way Analysis of Variance (ANOVA) and significant differences were reported at $95 \%$ confidence level using Tukey's test.

\section{Results and Discussion}

\subsection{Physicochemical Characteristics of Yam Starches}

Table 1. Physicochemical composition of Dioscorea rotundata starches

\begin{tabular}{|c|c|c|c|c|}
\hline Parameters (\%) & Asobayere & Labreko & Pona & Muchumudu \\
\hline Moisture & $7.82 \pm 0.05^{\mathrm{a}}$ & $7.41 \pm 0.06^{b}$ & $7.22 \pm 0.04^{\mathrm{c}}$ & $7.50 \pm 0.03^{b}$ \\
\hline Ash & $0.55 \pm 0.01^{\mathrm{a}}$ & $0.86 \pm 0.04^{b}$ & $0.24 \pm 0.02^{\mathrm{c}}$ & $0.47 \pm 0.02^{\mathrm{d}}$ \\
\hline Starch yield & $20.89 \pm 0.10^{\mathrm{a}}$ & $14.23 \pm 0.04^{b}$ & $15.63 \pm 0.06^{\mathrm{c}}$ & $12.61 \pm 0.12^{\mathrm{d}}$ \\
\hline $\mathrm{pH}$ & $5.57 \pm 0.01^{\mathrm{a}}$ & $6.25 \pm 0.01^{\mathrm{b}}$ & $5.74 \pm 0.01^{\mathrm{c}}$ & $6.11 \pm 0.01^{\mathrm{d}}$ \\
\hline Amylose & $27.48 \pm 0.47^{\mathrm{a}}$ & $31.55 \pm 0.47^{b}$ & $30.36 \pm 0.47^{b}$ & $28.57 \pm 0.47^{\mathrm{a}}$ \\
\hline Amylopectin & $72.52 \pm 0.47^{\mathrm{a}}$ & $68.45 \pm 0.47^{b}$ & $69.64 \pm 0.47^{b}$ & $71.43 \pm 0.47^{\mathrm{a}}$ \\
\hline Swelling Power & $10.57 \pm 0.04^{\mathrm{a}}$ & $10.74 \pm 0.01^{\mathrm{b}}$ & $12.48 \pm 0.02^{\mathrm{c}}$ & $12.14 \pm 0.07^{\mathrm{a}}$ \\
\hline Solubility & $8.90 \pm 0.09^{\mathrm{a}, \mathrm{b}, \mathrm{c}}$ & $8.52 \pm 0.02^{\mathrm{a}, \mathrm{d}}$ & $8.73 \pm 0.01^{\mathrm{c}, \mathrm{d}}$ & $9.32 \pm 0.05^{\mathrm{b}}$ \\
\hline WBC & $176.47 \pm 0.52^{\mathrm{a}}$ & $178.47 \pm 0.47^{\mathrm{b}}$ & $175.25 \pm 0.26^{\mathrm{a}}$ & $182.69 \pm 0.25^{\mathrm{c}}$ \\
\hline
\end{tabular}

WBC -Water binding capacity. Means followed by the same superscripts in a row denote values that are not significantly different at $\mathrm{p}<0.05$

The physicochemical compositions of the Dioscorea rotundata starches from the four varieties are presented in Table 1. Moisture contents varied significantly at $\mathrm{p}<0.05$. Asobayere recorded the highest moisture content of $7.82 \%$ for the starches. Labreko, Pona and Muchumudu had 7.41, 7.22 and $7.50 \%$ respectively. Good quality starch should have moisture content of in the range of $10-13.5 \%$ to ensure better shelf life ([16]; [25]). The moisture levels were however below this range. This may be as a result of a longer drying period of the starches after extraction. Hence, drying periods can be monitored and regulated to ensure that moisture content of these starches fall within the acceptable range. Comparable results have been reported from tubers of taro (Colocasia esculenta var. antiquorum), yam (Dioscorea alata) and sweet potato (Ipomoea batatas var. Beauregard) that have moisture contents of $8.99,11.16$ and $9.06 \%$ respectively. Ash level may also be regarded as a measure of the quality or grade of the flour and often a useful criterion in identifying the 
authenticity of food [26] and it also measures the mineral status of a sample. A significant difference $(p<0.05)$ was observed in the ash contents of the four varieties of yam starches. The ash content ranged from 0.24 (Pona) to $0.86 \%$ (Asobayere). Soil types and varietal differences may account for the differences in ash contents [27]. Ash content of less than or equal to $0.20 \%$ is an indication of good quality starch [25]. Starches were of higher ash content than the acceptable range. $\mathrm{pH}$ is an essential measurement of eating quality since it contributes to taste [28]. The $\mathrm{pH}$ of the yam starches varied significantly $(\mathrm{p}<0.05)$ from 5.57 (Asobayere) to 6.25 (Labreko) and were above acceptable range of 4.7-5.3 [25]. Starch yields from the yams showed significant differences at $\mathrm{p}<0.05$. Asobayere had the highest yield of $20.89 \%$ and Muchumudu the lowest yield of $12.61 \%$.

Amylose-amylopectin ratio is one of the parameters reported to contribute to good textural attributes of root and tuber crops ([29]; [3]). Significant differences $(p<0.05)$ existed between amylose contents. Amylose contents were 27.48, 31.55, 30.36 and 28.57\% for Asobayere, Labreko, Pona and Muchumudu respectively. Amylose contents for tubers of Colocasia esculenta var. antiquorum, Dioscorea alata and Ipomoea batatas var. Beauregard were 14.45, 31.33 and 28.69 respectively. Amongst these tubers taro (Colocasia esculenta var. antiquorum) has the least amylose content. The general low content of amylose in samples indicates that when these starches are incorporated into food products, swelling of starch will be enhanced (Tester and Morisson, 1990). Amylopectin content ranged from 68.45 (Labreko) to $72.52 \%$ (Asobayere). The results indicate that Labreko had the highest amylose content and Asobayere had the lowest. Otegbayo [3] observed that boiled yam with superior eating qualities is characterized by high amylose, dry matter and starch contents. The high amount of amylose in Labreko may contribute to its mealiness.
Swelling power and solubility index provide evidence of the magnitude of interaction between starch chains within the amorphous and crystalline domains and also evidence of association bonding within the granules of yam starches. The higher the swelling index, the lower the associative forces ([30]; [31]). The swelling power of the starches showed significant difference between Pona and Labreko at $\mathrm{p}<0.05$. Pona recorded the highest value of $12.48 \%$ and Asobayere had the lowest value of $10.57 \%$. The results indicate that Pona starch may have the lowest associative forces and Asobayere may have the highest associative forces. Soni [32] attributed high solubility indices in starches to the easy breakdown of the linear fraction (amylose) which is released or leached out during the swelling process. Solubility indices varied significantly at $\mathrm{p}<0.05$. Asobayere, Labreko, Pona and Muchumudu had 8.90, 8.52, 8.73 and $9.32 \%$ respectively for solubility indices. Riley [15] reported that solubility increased with decreasing amylose content in Dioscorea alata cultivars. This observation is similar with results obtained for Asobayere and Muchumudu. However, this is observation is dissimilar to the findings of Soni [32] who associated high solubility with high amylose content. The difference in the two studies could be attributed to varietal differences, ecological effect, tuber maturity, and differences in granule sizes and their arrangement within their cells [33].

Water binding capacity is important in texture and quality of some foods since they stabilize starches against effects such as syneresis, which sometimes occur during retorting and freezing ([16]; [34]). The water binding capacities of the yam starches varied significantly $(\mathrm{p}<0.05)$ with Asobayere, Labreko, Pona, and Muchumudu recording 176.47, 178.47, 175.25 , and $182.69 \%$ respectively. The results indicate that Muchumudu had the highest water binding capacity and thus, may be better for use in products that require high unit yield.

Table 2. Pasting properties of Dioscorea rotundata starches

\begin{tabular}{lllll}
\hline Parameters & Asobayere & Varieties Labreko & Pona & Muchumudu \\
\hline Pasting Temperature $\left({ }^{\circ} \mathrm{C}\right)$ & 75.1 & 75.5 & 75.7 & 77.3 \\
Pasting Time (min) & 17.40 & 17.55 & 18.05 & 19.10 \\
Peak Temperature $\left({ }^{\circ} \mathrm{C}\right)$ & 81.7 & 90.1 & 84.3 & 94.8 \\
Peak Viscosity $(\mathrm{BU})$ & 726 & 685 & 614 & 639 \\
Viscosity at $95^{\circ} \mathrm{C}(\mathrm{BU})$ & 586 & 547 & 395 & 605 \\
$\mathrm{HPV}(\mathrm{BU})$ & 340 & 542 & 320 & 614 \\
Viscosity at $50^{\circ} \mathrm{C}(\mathrm{BU})$ & 570 & 876 & 401 & 791 \\
$\mathrm{CPV}(\mathrm{BU})$ & 596 & 758 & 385 & 817 \\
Paste stability at $95^{\circ} \mathrm{C}$ & -246 & -5 & -75 & 9 \\
Paste stability at $50^{\circ} \mathrm{C}$ & $26^{\mathrm{a}}$ & -118 & -16 & $26^{\mathrm{a}}$ \\
Breakdown $(\mathrm{BU})$ & 385 & 142 & 293 & 25 \\
Setback (BU) & 229 & 337 & 79 & 176 \\
\hline
\end{tabular}

Means followed by the same superscripts in a row denote values that are not significantly different at $\mathrm{p}<0.05$

\subsection{Pasting Properties of Dioscorea Rotundata Starches}

Pasting properties are important functional characteristics of starches. When an aqueous suspension of starch is heated above a critical temperature, granules swell irreversibly and amylose leaches out into the aqueous phase, resulting into increased viscosity (pasting) [35]. The pasting properties of starches processed from four yam varieties are presented in Table 2.

The pasting temperature provides an indication of the minimum temperature required for sample cooking, energy cost involved and other components stability [31]. It also gives an indication of the gelatinization time during processing [36]. Oguntunde [37] reported that the associative bonding of the 
amylose fraction is responsible for the structure and pasting behaviour of starch granule. The pasting temperatures of yam starches in this study varied significantly at $p<0.05$. The pasting temperatures of the starches ranged from 75.1 to $77.3^{\circ} \mathrm{C}$ with Asobayere having the lowest and Muchumudu the highest. It can also be observed from the results (Table 2) that the higher the pasting temperature, the longer the pasting time. Asobayere and Labreko had the lower pasting times (17.40 and $17.55 \mathrm{~min}$ ) and pasting temperatures (75.1 and $75.5^{\circ} \mathrm{C}$ ) respectively and therefore may be most appropriate for the production of foods that require shorter processing time. The peak temperatures of yam starches showed significant difference at $\mathrm{p}<0.05$. Asobayere, Labreko, Pona and Muchumudu had $81.7,90.1,84.3$ and $94.8^{\circ} \mathrm{C}$ respectively. Work by Aprianita et al. (2009) shows that tubers of Colocasia esculenta var. antiquorum, Dioscorea alata and Ipomoea batatas var. Beauregard have comparable pasting temperatures within a range of $64.4-72.8^{\circ} \mathrm{C}$. However, their pasting time values were relatively lower ranging from 7.3-8.5min.

Peak viscosity is a measure of the ability of starch to form a paste. It is also the ability of starch to swell freely before their physical breakdown [38]. Peak viscosity has been reported to be closely associated with the degree of starch damage. According to Sanni [39], high starch damage results in high peak viscosity. Peak viscosities of starches varied significantly at $\mathrm{p}<0.05$. Asobayere had the highest peak viscosity of $726 \mathrm{BU}$ whiles Pona had the lowest (614 BU). The high peak viscosity observed in Asobayere implies that it may be suitable for products requiring high gel strength, thick paste and elasticity pounded yam. High peak viscosity is an indication of high starch content ([40]; [41]; [42]). Asobayere recorded the highest starch yield (Table 1). This may explain its high peak viscosity. The difference in peak viscosities may be due to differences in starch contents. Aprianita et al. (2009) reported that sweet potato had peak viscosity of $1238 \mathrm{BU}$ and this could be due to its high starch $(84.15 \%)$ content as well.

With regards to viscosity at $95^{\circ} \mathrm{C}$, Pona had the lowest viscosity (395 BU) and Muchumudu had the highest (605 BU). Paste stability at $95^{\circ} \mathrm{C}$ for the yam starches also ranged from -246 BU for Asobayere and 9 BU for Muchumudu. Paste stability reflects the strength of the starch pastes [28]. According to Oduro [28], flour with low paste stability has very weak cross-linking within the starch granules and requires less cooking time. Asobayere had the lowest paste stability, and hence may have very weak cross-linking. Asobayere also had the lowest pasting time (17.4 min) which is reflective of a shorter cooking time.

Holding strength measures the ability of starch to remain undisrupted when yam paste is subjected to a long duration of high, constant temperature during the process of steaming [30]. After a $15 \mathrm{~min}$ hold at $95^{\circ} \mathrm{C}$, viscosities (Hot Paste Viscosity) observed ranged from $320 \mathrm{BU}$ (Pona) to $614 \mathrm{BU}$ (Muchumudu). There was a general increase in viscosity when paste was cooled to $50^{\circ} \mathrm{C}$. Final viscosity formed at the end of cooling at $50^{\circ} \mathrm{C}$ is called cold paste viscosity (CPV). This viscosity is an important property if extruded starch is to be used as an ingredient in foods that require cold thickening capacity like instant creams, sauces or [43]. CPV's ranged from $385 \mathrm{BU}$ (Pona) to $817 \mathrm{BU}$ (Muchumudu). The increase in CPV of all the starches could be attributed to the high retrogradation property of yam starch during cooling [44]. On the other hand, differences amongst varieties in CPV could be associated with differences in amylose contents. High amylose starches have been found to re-associate more readily than high amylopectin starches. This is because the linear chains can orient parallel to each other, moving close enough together to bond [42]. Collado [45] also reported that starches that have high cold positive viscosities are better for production of noodles. Thus, starches extracted from Muchumudu and Labreko may be better suited for production of noodles.

Breakdown measures the ability of starch to withstand collapse during cooling or the degree of disintegration of granules or paste stability ([30]; [47]). Adebowale [41] reported that the higher the breakdown in viscosity, the lower the ability of the sample to withstand heating and shear stress during cooking. Significant differences existed in breakdown viscosities of yam starches. Muchumudu and Asobayere had the lowest $(25 \mathrm{BU})$ and highest $(385 \mathrm{BU})$ breakdown viscosities respectively. From this study, Muchumudu had the highest ability to withstand heating and shear stress during cooking.

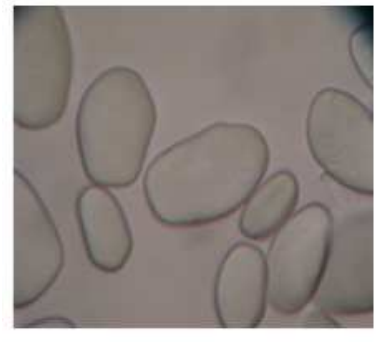

a)

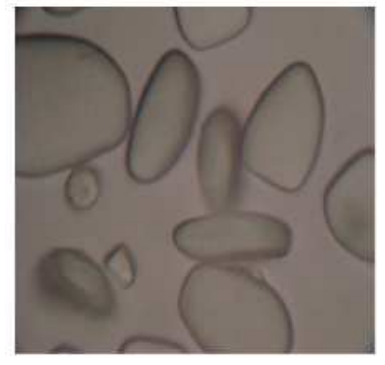

c)

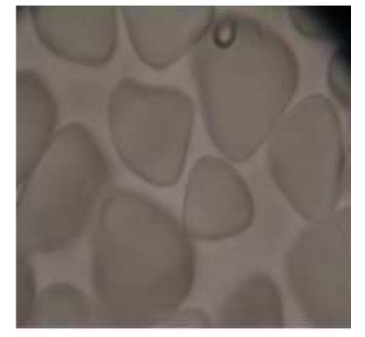

b)

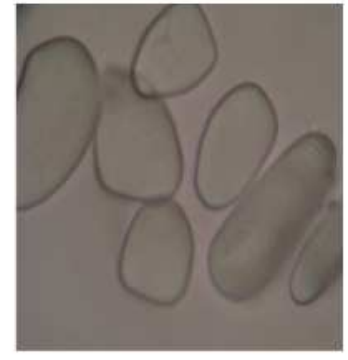

d)
Figure 1. Starch granule shapes (x400 magnification) a) Asobayere b) Labreko c) Muchumudu d) Pona

Setback measures the re-association of starch [30]. Kin [46] reported that a high setback value is associated with a cohesive paste while a low value is an indication of a non-cohesive paste. Significant differences were observed in yam starches at $\mathrm{p}<0.05$. Setback values ranged from 79 BU for Pona to 337 BU for Labreko. Low setback values are useful for products like weaning foods, which require low viscosity and paste 
stability at low temperatures [28], and as such Pona may be useful for such products. Conversely, starch from Labreko may be useful for products such as fufu and pounded yam that require high cohesive pastes.

\subsection{Granule Morphology of Dioscorea Rotundata Starches}

The starch granules of Asobayere, Labreko, Pona and
Muchumudu consisted of different shapes. These shapes are presented in Plates 4.2 to 4.5. Generally, most of the varieties exhibited spherical, elliptical to oval shaped granules. However, in Labreko a dominant proportion of angular shaped granules were observed. A small proportion of angular shaped granules were also observed in Pona and Muchumudu. Starch granules were predominantly oval and elliptical in Asobayere.

Table 3. Mean granule size and size distribution of extracted starch granules

\begin{tabular}{lllll}
\hline Parameters & Small & Granule size $(\boldsymbol{\mu m})$ Medium & Large & Extra large \\
\hline Asobayere & $9.88 \pm 0.00^{\mathrm{a}}$ & $17.29 \pm 0.00^{\mathrm{a}}$ & $43.22 \pm 2.14^{\mathrm{a}}$ & $56.81 \pm 0.00^{\mathrm{a}}$ \\
Labreko & $11.53 \pm 1.43^{\mathrm{b}}$ & $18.11 \pm 1.43^{\mathrm{a}}$ & $55.99 \pm 1.43^{\mathrm{b}}$ & $60.93 \pm 1.43^{\mathrm{b}}$ \\
Pona & $10.70 \pm 1.43^{\mathrm{b}}$ & $23.47 \pm 1.24^{\mathrm{b}}$ & $56.81 \pm 0.00^{\mathrm{b}}$ & $66.28 \pm 0.71^{\mathrm{c}}$ \\
Muchumudu & $7.82 \pm 0.72^{\mathrm{c}}$ & $13.17 \pm 1.42^{\mathrm{c}}$ & $42.81 \pm 2.85^{\mathrm{a}}$ & $59.28 \pm 0.00^{\mathrm{d}}$ \\
\hline
\end{tabular}

Means followed by the same superscripts in a column denote values that are not significantly different at $\mathrm{p}<0.05$

Table 4. Some functional properties of Dioscorea rotundata flours and starches

\begin{tabular}{|c|c|c|c|c|c|c|c|c|}
\hline Parameters (\%) & Flour Aso & Lab & Pona & Much & Starch Aso & Lab & Pona & Much \\
\hline Swelling power & $\begin{array}{l}10.16 \\
\pm 0.01^{\mathrm{a}}\end{array}$ & $\begin{array}{l}11.12 \\
\pm 0.04^{b}\end{array}$ & $12.26 \pm 0.02^{\mathrm{c}}$ & $10.92 \pm 0.02^{\mathrm{d}}$ & $10.57 \pm 0.04^{\mathrm{a}}$ & $10.74 \pm 0.01^{\mathrm{b}}$ & $12.48 \pm 0.02^{\mathrm{c}}$ & $12.14 \pm 0.07^{\mathrm{a}}$ \\
\hline Solubility & $9.40 \pm 0.03^{\mathrm{a}}$ & $9.21 \pm 0.08^{\mathrm{b}}$ & $8.89 \pm 0.03^{c}$ & $9.39 \pm 0.01^{\mathrm{a}}$ & $\begin{array}{l}8.90 \\
\pm 0.09^{\mathrm{a}, \mathrm{b}, \mathrm{c}}\end{array}$ & $8.52 \pm 0.02^{\mathrm{a}, \mathrm{d}}$ & $8.73 \pm 0.01^{\mathrm{c,d}}$ & $9.32 \pm 0.05^{\mathrm{b}}$ \\
\hline WBC & $\begin{array}{l}215.20 \\
\pm 0.14^{\mathrm{a}}\end{array}$ & $\begin{array}{l}218.30 \\
\pm 0.19^{\mathrm{b}}\end{array}$ & $216.87 \pm 0.07^{\mathrm{c}}$ & $232.45 \pm 0.23^{d}$ & $\begin{array}{l}176.47 \\
\pm 0.52^{\mathrm{a}}\end{array}$ & $\begin{array}{l}178.47 \\
\pm 0.47^{\mathrm{b}}\end{array}$ & $175.25 \pm 0.26^{\mathrm{a}}$ & $182.69 \pm 0.25^{\circ}$ \\
\hline
\end{tabular}

Aso - Asobayere; Lab- Labreko; Much- Muchumudu; WBC - Water binding capacity. Means followed by the same superscripts in a row denote values that are not significantly different at $\mathrm{p}<0.05$. Values are means \pm standard deviation.

Table 5. Pasting properties of Dioscorea rotundata flours

\begin{tabular}{|c|c|c|c|c|}
\hline Parameters & Asobayere & Varieties Labreko & Pona & Muchumudu \\
\hline Pasting Temperature $\left({ }^{\circ} \mathrm{C}\right)$ & $77.0^{\mathrm{a}}$ & $73.4^{\mathrm{b}}$ & $76.2^{c}$ & $79.2^{\mathrm{d}}$ \\
\hline Pasting Time (min) & $18.50^{\mathrm{a}}$ & $17.15^{\mathrm{b}}$ & $18.10^{\mathrm{c}}$ & $20.05^{\mathrm{d}}$ \\
\hline Peak Temperature $\left({ }^{\circ} \mathrm{C}\right)$ & $94.7^{\mathrm{a}}$ & $94.7^{\mathrm{a}}$ & $94.6^{\mathrm{b}}$ & $94.6^{\mathrm{b}}$ \\
\hline Peak Viscosity (BU) & $575^{a}$ & $499^{b}$ & $437^{c}$ & $290^{d}$ \\
\hline Viscosity at $95^{\circ} \mathrm{C}(\mathrm{BU})$ & $557^{\mathrm{a}}$ & $444^{b}$ & $385^{c}$ & $171^{\mathrm{d}}$ \\
\hline HPV (BU) & $460^{\mathrm{a}}$ & $480^{b}$ & $431^{\mathrm{c}}$ & $288^{\mathrm{d}}$ \\
\hline Viscosity at $50^{\circ} \mathrm{C}(\mathrm{BU})$ & $578^{a}$ & $596^{b}$ & $481^{\mathrm{c}}$ & $338^{\mathrm{d}}$ \\
\hline Paste stability at $95^{\circ} \mathrm{C}$ & $-97^{a}$ & $36^{\mathrm{b}}$ & $46^{c}$ & $117^{\mathrm{d}}$ \\
\hline Paste stability at $50^{\circ} \mathrm{C}$ & $0^{\mathrm{a}}$ & $-27^{b}$ & $-7^{c}$ & $-25^{d}$ \\
\hline Breakdown (BU) & $115^{\mathrm{a}}$ & $18^{\mathrm{b}}$ & $6^{\mathrm{c}}$ & $2^{d}$ \\
\hline Setback (BU) & $118^{\mathrm{a}}$ & $113^{b}$ & $50^{\mathrm{c}}$ & $49^{d}$ \\
\hline
\end{tabular}

HPV- Hot Paste Viscosity CPV- Cold Paste Viscosity BU- Brabender Unit

Means followed by the same superscripts in a row denote values that are not significantly different at $\mathrm{p}<0.05$

Granule size and size distribution of the yam starches are presented in Table 3. Mean granule size varied from 25.94 for Muchumudu to $32.06 \mu \mathrm{m}$ for Pona. Granule sizes ranged from 9.88 to $56.81,10.10$ to $62.36,9.27$ to 66.99 and 7.10 to 59.28 $\mu \mathrm{m}$ for Asobayere, Labreko, Pona and Muchumudu respectively.

Pona showed the widest granule size distribution (9.27-66.99 $\mu \mathrm{m})$. These results are similar to reports from Farhat et al. (1999) and Zaidul et al. (2007) which indicate that yam and sweet potato flours and starches, had larger particles with a distribution that gave rise to two discrete peaks at 28.3 and $251 \mu \mathrm{m}$. Granule dimensions, size distribution and shape are characteristic of botanical source [47]. Granule shape and size are also important characteristics for the starch extraction industry since they define mesh size for application and purification sieves [48].
The granule size and shape affect the functional characteristics of starches and may influence their industrial uses [33]. Starch granule size contributes to the rate at which starch gelatinizes, its gelatinization temperature, swelling power and viscosity ([47]; [49]). Smaller granules have high molecular bonding which leads to lower swelling. Fortuna [50] also reported that large granules increase swelling. Pona had the largest granule size, therefore low molecular bonding and thus higher swelling. This confirms the high swelling power of Pona as shown in Tables 4 and 5.

\section{Conclusion}

The high amylose content in Labreko may contribute to good textural attributes (mealiness). Muchumudu may be used industrially for products that require high unit yield as well as 
products such as weaning foods that require low viscosity and paste stability at low temperatures. Muchumudu and Labreko may also be suitable for production of noodles. Muchumudu may have the highest ability to withstand heating and shear stress during cooking.

Asobayere can be exploited for starch production because of its high starch yield. The extracted starch may be used in the industries or for food products that require thick paste, high gel strength and elasticity. Asobayere and Labreko may be used in the preparation of pounded yam and fufu. Starches from Asobayere and Labreko can also be employed in food preparations that require shorter processing time. Pona may be favourable for the preparation of weaning foods.

Asobayere, Labreko, Pona and Muchumudu can also serve as alternate sources of starch based on their unique characteristics and thus, can be used for diverse products.

\section{References}

[1] F. D. Baah, B. Maziya-Dixon, R. Asiedu, I. Oduro and W. O. Ellis. Nutritional and biochemical composition of D. alata (Dioscorea spp.) tubers. Journal of Food, Agriculture \& Environment, 7 (2): 373-378, 2009.

[2] N. G. Amani, A. Buléon, A. Kamenan and P. Colonna. Variability in starch physicochemical and functional properties of yam (Dioscorea spp.) cultivated in Ivory Coast. Journal of the Science of Food and Agriculture, 84: 2085-2096, 2004.

[3] B. O. Otegbayo, A. U. Achidi, R. Asiedu, and M. Bokanga. Food quality attributes of Pona yams. Proceedings of the Eighth Triennial Symposium of the International Society for Tropical Root Crops, Ibadan, Nigeria. 12-16 November, 2001.

[4] A. A. Markson, G. Omosun, B. E. Madunagu, A. C. Amadioha, and R. Wokocha. Physicochemical alteration of tissues of white yam (Dioscorea rotundata Poir) tubers incited by Botryoiplodia theobromae Pat. International Journal ofCurrent Research, 4: 055-061, 2010.

[5] L. Sebio, and Y. K. Chang, Effects of selected process parameters in extrusion of yam flour (Dioscorea rotundata) on physicochemical properties of the extrudates. Nahrung, 44 (2): $96-101,2000$.

[6] D. J. Gallant, H. Bewa, Q. H. Buy, B. Bouchet, O. Szylit and L. Sealy. Ultrastructural and nutritional aspects of some tropical tuber starches. Starch/Stärke, 34: 255-262, 1982.

[7] W-M Wang, V. M-F. Lai, K-F. Chang, S. Lu, and H-H. Ho. Effect of amylopectin structure on the gelatinization and pasting properties of selected yam (Dioscorea spp.) starches. Starch/Stärke, 58: 572-579, 2006.

[8] S. Asuming-Brempong. Yam for foreign exchange: potentials and prospects in Ghana; ISHS Acta Horticulture 380, Symposium on Tropical Root Crops in a Developing Economy, November 1994.

[9] ISSER. The state of the Ghanaian economy in 2005, Institute of Statistical, Social and Economic Research (ISSER), University of Ghana, Legon, Accra, 2006.

[10] Millennium Development Authority (MiDA). Investment opportunity Ghana: Yam seed production. p. 2, 2009.
[11] R. J. Alexander. Starch in plastics. Cereal Foods World 41: 426-427, 1996.

[12] C. Ostertag. World production and marketing of starch. In: Cassava flour and starch: progress in research and development. California. Columbia, pp. 105-120, 1996.

[13] J. A. Woolfe. Sweet potato an untapped food resource. Cambridge University Press. UK. p. 643, 1992.

[14] FAO. Global cassava market study, Food and Agriculture Organization. Rome. Italy, 2000.

[15] C. K. Riley, A. O. Wheatley and H. N. Asemota. Isolation and characterization of starches from eight Dioscorea alata cultivars grown in Jamaica. African Journal of Biotechnology 5 (17): 1528-1536, 2006.

[16] W. O. Ellis, I. Oduro, J. Barimah and J. A. Otoo. Quality of starch from six Japanese sweet potato varieties in Ghana. African Journal of Root and Tuber Crops, 5(2): 38-41, 2003.

[17] Official Methods of Analysis. 15th Edition. Association of Official Analytical Chemists, Washington, DC, (AOAC, 1990).

[18] V. R. Williams, W. Wu, H. Y. Tsai and Bates. Varietal differences in amylose content of rice starch. Journal of Agricultural and Food Chemistry, 6: 47-48, 1958.

[19] B. O. Juliano. A simplified assay for milled rice amylose. Cereal Science Today, 16: 334-340, 1971.

[20] W. T. Yamazaki. An alkaline water retention test for the evaluation of cooking and baking potentialities of soft water wheat flour. Cereal Chemistry, 30: 242- 246, 1953.

[21] D. G. Medcalf and K. A. Gilles. Wheat starches: comparison of physicochemical properties. Cereal Chemistry, 42: 558-568, 1965.

[22] H. W. Leach, D. L. McCowen and T. J. Schoch. Swelling and solubility patterns of various starches and structure of starch granule. Cereal Chemistry, 36: 534-544, 1959.

[23] W. C. Shuey, and N. H. Tipples. The amylograph handbook. The American Association of Cereal Chemists. pp. $32-35$, 1980.

[24] C. E. Walker, A. S. Ross, C. W. Wrigley, and J. McMaster. Accelerated starch- paste characterization with rapid viscoanalyzer. Cereal Foods World, 33: 149-494, 1988.

[25] I. C. Onwueme. The tropical tuber crop. John Wiley and Sons, Chinchester (UK). pp. 189-191, 1982.

[26] L. W. Aurand, A. E. Woods and M. R. Wells. Food composition and analysis. Van Nostrand Reinhold Publishers. New York (U.S.A). pp 513-515, 1987.

[27] A. U. Osagie. Physiology and biochemistry of the yam tuber In: The yam tuber in storage. Post-harvest Research Unit, Department of Biochemistry, University ofBenin, Nigeria, 1992.

[28] I. Oduro, W. O.Ellis, L. Nyarko, G. Koomson, and J. A. Otoo. Physicochemical and pasting properties of flour from four sweetpotato varieties in Ghana. Proceedings of the Eigth Triennial Symposium of the International Society for Tropical Root Crops (ISTRC-AB), Ibadan, Nigeria. 12-16 November, 2001. 
[29] A. O. Olorunda, O. C. Aworth and F. A. Numfor,. Technical note. Predicting quality of cassava product with the aid of chemical and rhoelogical properties.Journal of Food Technology, 16: 447-450, 1981.

[30] K. O. Jimoh, T. O. Olurin and J. O. Aina. Effect of drying methods on the rheological characteristics and colour of yam flours. African Journal of Biotechnology, 8 (10): 2325-2328, 2009.

[31] O. J. Ikegwu, V. N. Nwobasi, M. O. Odoh and N. U. Oledinma. Evaluation of thepasting and some functional properties of starch isolated from some improved cassava varieties in Nigeria. African Journal of Biotechnology, 8 (10): 2310-2315, 2009.

[32] R. L. Soni, S. S. Sharma, D. Dun, M. M. Gharia and J. Ahmedabad. Physico chemical properties of Quercus leucotrocophora (oak), Starch/Starke, 45 (4): 127-130, 1993.

[33] F. D. Baah. Characterization of water yam (Dioscorea alata) for existing and potential food products. Doctoral thesis. Kwame Nkrumah University of Science and Technology, Kumasi, 2009.

[34] R. C. Baker, P. Wonghan and K. R. Robbins. Fundamentals of new food products developments. Science, Volume 16. Elsevier Science Amsterdam, 1994.

[35] C. Brabet, D. Reynoso, D. Dufour, C. Mestres, J. Arredondo, and G. Scott. Starch content and properties of 106 sweetpotato clones from the world germplasm collection held at CIP, Peru. International Potato Centre. Lima, Peru, 1998.

[36] J. O. Odedeji and R. O. Adeleke. Pasting characteristics of wheat and sweet potato flour blends. Pakistan Journal of Nutrition, 9 (6): 555-557, 2010.

[37] A. O. Oguntunde. Review: Starch modification for food application. Nigerian Food Journal, 5: 102-107, 1987.

[38] L. O. Sanni, S. B. Kosoko, A. A. Adebowale and R. J. Adeoye. The influence of palm oil and chemical modification on the pasting and sensory properties of fufu flour. International Journal of Food Properties, 7: 229-237, 2004.

[39] L. O. Sanni, D. P. Ikuomola and S. A. Sanni. Effect of length of fermentation and varieties on the qualities of sweet potato gari. Proceedings of the Eighth TriennialSymposium of the International Society for Tropical Root Crops, Ibadan, Nigeria. 12- 16 November, 2001. pp. 208-211, 2001.

[40] T. O. Osungbaro. Effect of differences in variety and dry milling of maize on texture characteristics of ogi. Journal of Food and Agriculture, 54: 1-11, 1990.

[41] A. A. Adebowale, L. O. Sanni and S. O. Awonorin. Effect of texture modifiers on the physicochemical and sensory properties of dried fufu. Food Science Technology International, 1 (5): 373-382, 2005.
[42] A. E. Shimelis, M. Meaza and S. Rakshit. Physico-chemical properties, pasting behavior and functional characteristics of flours and starches from improved bean (Phaseolus Vulgaris L.) varieties grown in East Africa. CIGR e-journals, 8: 1- 18, 2006.

[43] R. M. L. Alves, M. V. E. Grossmann and R. S. S. F. Silva. Gelling properties of extruded yam (Dioscorea alata) starch. Food Chemistry, 67 (2): 123-127, 1999.

[44] E. O. Afoakwa and S. Sefa-Dedeh. Chemical composition and quality changes occurring in Dioscorea dumetorum pax tubers after harvest. Food Chemistry, 75: 85-91, 2001.

[45] L. S. Collado, L. B. Mabesa, C. G. Oates and H. Corke. Bihon-type noodles from heat-moisture-treated sweet potato starch. Journal of Food Science, 66: 604-609, 2001.

[46] Y. S. Kin, D. P. Wiesenborn, P. H. Orr and L. A. Grant. Screening potato starch for novel properties using differential scanning calorimetry. Journal of Food Science, 60: 1060-1065, 1995.

[47] M. Tsakama, A. M. Mwangwela, T. A. Manani and N. M. Mahungu. Physicochemical and pasting properties of starch extracted from eleven sweetpotato varieties. African Journal of Food Science and Technology, 1 (4): 090-098, 2010.

[48] M. Leonel, S. B. S. Sarmento, and M. P. Cereda. New starches for the food industry: Curcuma longa and Curcuma zedoaria. Carbohydrate Polymers 54: 385-388, 2003.

[49] N. Singh, J. Singh, L. Kaur, N. S. Sodhi, and S. B. Gill. Morphological, thermal and rheological properties of starches from different botanical sources. Food Chemistry, 81:219-231, 2003.

[50] T. Fortuna, R. Januszewska, L. Juszczak, A. Kielski, and M. Palasinski. The influence of starch pore characteristics on pasting behaviour. International Journal of Food Science and Technology, 35:285-291, 2000.

[51] R. F. Tester and W. R. Morrison. Swelling and gelatinization of cereal starches. I. Effect of amylopectin, amylose and lipids. Cereal Chemistry, 67:551-559, 1990.

[52] A. Aprianita, U. Purwandari, B. Watson and T. Vasiljevic. Physico-chemical properties of flours and starches from selected commercial tubers available in Australia. International Food Research Journal 16: 507-520, 2009.

[53] I. A. Farhat, T. Oguntona and R. J. Neale. Characterization of starches from West African yams. Journal of the Science of Food and Agriculture 79:2105-2112, 1999.

[54] I. S. M. Zaidul, N. A. N. Norulaini, A. K. M. Omar, H. Yamauchi and T. Noda. RVA analysis of mixtures of wheat flour and potato, sweet potato, yam, and cassava starches. Carbohydrate Polyners 69: 784-791, 2007. 